UDC 528.71/73:71.72.02

DOI: 10.30838/J.BPSACEA.2312.170118.82.44

\title{
3D PHOTOGRAMMETRY APPLICATION FOR BUILDING INSPECTION OF CULTURAL HERITAGE OBJECTS
}

MARKOVA M. ${ }^{1}$, Cand. Sc. (Tech.), KRAVCHENKO D. ${ }^{2}$, engineer

${ }^{1}$ Nastroy LLC, 27 Omelchenka str., Zaporizhia city, 69068, Ukraine, email: markova.mari@gmail.com

${ }^{2}$ Nastroy LLC, 27 Omelchenka str., Zaporizhia city, 69068, Ukraine, email: dmitriykravchenko93@gmail.com

Abstract. Landmarked buildings require periodic inspection and restoration. Numerous techniques are known that allow engineers to perform detailed inspection of buildings and structures. In recent decades, 3D scanning and photogrammetry application for building inspection spread around. The purpose of the study is to develop the most effective approach to aerial photography with the use of UAV to create precise model of the building. Methodology. The technique is based on the creation of three-dimensional model out of 2-dimensional photographs with the help of dedicated software. Scientific novelty can be considered as the development of an algorithm for programming the UAV flight along the most optimal trajectory in order to obtain a sufficient number of images, and consequently constructing a model with the least number of distorted sections. The result of the work is a three-dimensional model of a building or structure with all actual sizes and textures preserved. Obtained model can be later used for a detailed study of the damages of the existing structural and architectural elements of building; also, it can be used as a background model for the reconstruction or restoration project design, depending on the research objectives. The practical significance of this method is demonstrated by the inspection of the actual landmarked building: the Mennonite school in Zaporizhia city. The inspected building was built in the late nineteenth century and has not changed its functional purpose until today. The building is one of the few well-preserved examples of authentic Mennonite architecture in the region, therefore a great deal of attention was paid for inspection and elaboration the measures for its restoration. A complex inspection was performed using 3D photogrammetric survey and creation of a three-dimensional model. Using the model, the places that need to be restored are precisely identified, and the defects that need to be eliminated are identified. The technical condition of the structures is estimated even in hard-to-reach places. Thus, it is clearly shown that the presented inspection technique significantly reduces labor intensity and raises the efficiency of building and structures inspection.

Keywords: building inspection; $3 D$ modeling; $3 D$ photogrammetry; $3 D$ scanning; landmarked buildings preservation; heritage objects capturing

\section{ЗАСТОСУВАННЯ ЗD ФОТОГРАММЕТРІЇ ДЛЯ ОБСТЕЖЕННЯ ОБ'СКТІВ КУЛЬТУРНОЇ СПАДЩИНИ}

МАРКОВА М. ${ }^{1}$, канд. техн. наук, КРАВЧЕНКО Д. ${ }^{2}$, інж.

${ }^{1}$ ТОВ «Настрой», вул. Омельченка, 27, Запоріжжя, 69068, Україна, email: markova.mari@gmail.com

${ }^{2}$ ТОВ «Настрой», вул. Омельченка, 27, Запоріжжя, 69068, Україна, email: dmitriykravchenko93@gmail.com

Анотація. Пам'ятки архітектури вимагають періодичного обстеження і реставрації. Існують численні методики, що дозволяють детально обстежити будівлі і споруди. В останні десятиліття великого поширення набув спосіб обстеження із застосуванням 3D сканування і фотограмметрії. Мета дослідження - розроблення найбільш ефективного підходу до аерофотозйомки із застосуванням БПЛА для побудови найбільш точної моделі будівлі. Методологія. Методика будується на побудові з двовимірних фотознімків за допомогою спеціального програмного забезпечення тривимірної моделі. Науковою новизною можна вважати розробку алгоритму для програмування польоту БПЛА по найбільш оптимальній траєкторії 3 метою отримання достатньої кількості знімків і, отже, побудови моделі з найменшою кількістю спотворених ділянок. Результат роботи - тривимірна модель будівлі або споруди зі збереженням усіх фактичних розмірів і текстур. Модель у подальшому може бути застосована як для детального дослідження дефектів існуючих конструкцій і елементів будівлі, так і як підоснова для розроблення креслень для проекту реконструкції або реставрації залежно від мети дослідження. Практичне значення цієї методики продемонстровано під час обстеження реального об'єкта культурної спадщини: це менонітська школа в м. Запоріжжя. Будівля, що обстежувалась побудована в кінці XIX століття і донині не змінила функціонального призначення. Ця споруда - один із небагатьох добре збережених зразків автентичної менонітської архітектури в цьому регіоні, тому було приділено велику увагу обстеженню і розробленню заходів 3 їі відновлення. Виконано комплексне обстеження із застосуванням фотограмметричної зйомки і побудовою тривимірної моделі. 3 використанням моделі точно встановлено місця, що потребують відновлення, визначено дефекти, які потребують усунення. Оцінено стан конструкцій навіть у важкодоступних місцях. Таким чином наочно показано, що наведена методика обстеження істотно знижує трудомісткість і підвищує ефективність робіт з обстеження конструкцій. 
Ключові слова: обстеження; 3D моделювання; 3D фотограмметрія; 3D сканування; пам'ятки архітектури

\section{ПРИМЕНЕНИЕ 3D ФОТОГРАММЕТРИИ ДЛЯ ОБСЛЕДОВАНИЯ ОБЪЕКТОВ КУЛЬТУРНОГО НАСЛЕДИЯ}

МАРКОВА М. ${ }^{1}$, канд. техн. наук, КРАВЧЕНКО Д. ${ }^{2}$, инж.

${ }^{1} \mathrm{OOO} \mathrm{«Настрой»,} \mathrm{ул.} \mathrm{Омельченко} \mathrm{27,} \mathrm{Запорожье,} \mathrm{69068,} \mathrm{Украина,} \mathrm{email:} \mathrm{markova.mari@gmail.com}$

${ }^{2} \mathrm{OOO} \mathrm{«Настрой»,} \mathrm{ул.} \mathrm{Омельченко} \mathrm{27,} \mathrm{Запорожье,} \mathrm{69068,} \mathrm{Украина,} \mathrm{email:} \mathrm{dmitriykravchenko93@gmail.com}$

Аннотация. Памятники архитектуры требуют периодического обследования и реставрации. Известны многочисленные методики, позволяющие детально обследовать здания и сооружения. В последние десятилетия большое распространение получил способ обследования с применением 3D сканирования и фотограмметрии. Целью исследования является разработка наиболее эффективного подхода к аэрофотосъемке с применением UAV для построения наиболее точной модели здания. Методика основывается на построении из двумерных фотоснимков при помощи специального программного обеспечения трехмерной модели. Научной новизной можно считать разработку алгоритма для программирования полета БПЛА по наиболее оптимальной траектории с целью получения достаточного количества снимков, и, следовательно, построения модели с наименьшим количеством искаженных участков. Результатом работы является трехмерная модель здания или сооружения с сохранением всех фактических размеров и текстур, которая впоследствии может быть применена как для детального исследования дефектов существующих конструкций и элементов здания, так и в качестве подложки для разработки чертежей для проекта реконструкции или реставрации в зависимости от целей исследования. Практическое значение данной методики продемонстрировано при обследовании реального объекта культурного наследия: менонитской школы в г. Запорожье. Обследуемое здание построено в конце XIX века и до сегодняшних дней не поменяло функционального назначения. Здание является одним из немногих хорошо сохранившихся образцов аутентичной менонитской архитектуры в этом регионе, поэтому было уделено большое внимание обследованию и разработке мероприятий по его восстановлению. Выполнено комплексное обследование с применением фотограмметрической съемки и построением трехмерной модели. С использованием модели точно установлены места, требующие восстановления, определены дефекты, требующие устранения. Оценено состояние конструкций даже в труднодоступных местах. Таким образом наглядно показано, что представленная методика обследования существенно снижает трудоемкость и повышает эффективность работ по обследованию конструкций.

Ключевые слова: обследование; $3 D$ моделирование архитектурных памятников; объекты культурного наследия

Introduction. There are not many landmarked buildings preserved in Zaporizhia region, Ukraine. Therefore, they especially need preservation and, consequently, periodic inspection and restoration.

Detailed measurements of buildings and structures - an integral part of the building inspection. Landmarked buildings often have a complex geometric shape, complex architectural forms of facades, complex crack and damage patterns that requires capturing as well in order to analyze their potential causes. Furthermore, a detailed survey is required to determine the technical state of all structural and architectural elements of the building for the restoration of the landmarked building.

It could be challenging to perform detailed measurements manually in practice, especially at height and in hard-to-reach elements of roofs, towers, etc. In addition, manual collecting of geometrical dimensions of elements are labor-intensive and the human factors error could occur which increases the cost and duration of surveys especially when big projects are concerned.

In comparison to a traditional manual approach, modern digital methods of 3D capturing provide very accurate representations of building's properties including the following: surface, structure, realistic visual presentation (textures). As far as landmarked building inspection is concerned, 3D capturing of building's elements using different methods has its wide practical use.

Currently, there are two main approaches to $3 \mathrm{D}$ virtual modeling that are used to create digital models of different subjects: 3D scanning and photogrammetry. 3D scanning based on using highly specialized equipment that measures and reconstructs the surface of an object using technology based on stereo vision, light wave, or sound wave distance measurement. Alternatively, photogrammetry 
methods extract information from 2D photographs to reconstruct objects in 3D.

Recently, low altitude unmanned aerial vehicles (UAV) expanded its practical application area in the construction industry. These vehicles fully meet the needs of $3 \mathrm{D}$ photogrammetry capturing of building-sized objects.

During the last decade, many studies concerning the use of 3D photogrammetry for building inspection were carried out. Practical use of 3D photogrammetry and 3D laser scanning combination is described in the case study of ancient theatre inspection [1]. Decreasing the time needed for documentation was shown. Comparison of two terrestrial photogrammetric methods - semiautomatic and automatic was provided in [2] - the case study of old military building capturing. In [3] the accuracy of the UAV-derived 3D models was assessed. The experiment showed that besides the Laser Scanner Systems, even the lowest cost systems based on UAV image processing and photogrammetric analysis with Structure from Motion algorithms are able to produce 3D models, with a good level of accuracy. In [4] practical use of Photogrammetry and aerial photography in the field of building inspection, as well as disaster assessment, is considered. Automated masonry crack detection using pictures taken by UAV is described in [5].

In this study, practical use of $3 \mathrm{D}$ photogrammetry capturing in the field of heritage objects inspection using an example of the monument of Mennonite architecture in Zaporizhia city is described.

To reconstruct a 3D model Autodesk ReCap Photo software was used. The main features of the obtained three-dimensional model are high geometrical accuracy, the presence of the textures, which allowed us to analyze in detail the technical state of structural elements, as well as various architectural details and assemblies. Such an analysis makes it possible to identify damage and structural defects that cannot be captured by visual inspection due to the inaccessibility and complexity of particular elements.

\section{The methodology of a building inspection: the case study of the monument of Mennonite architecture}

In order to illustrate the inspection methodology an example of a monument of Mennonite architecture is given. Mennonites appeared in Ukraine in the last decades of the XVIII century and made a significant contribution to the development of the region [6]. They developed highly productive agriculture, contributed to the development of industry, trade, and finance of the region. One of the few buildings that have retained their functional purpose is the building of the women's school (now Zaporozhia Comprehensive School No. 81) in the village of Rosenthal. The village was founded in 1790 , had one main street, which ran parallel to the river Khortitsa. Currently, Rosenthal is part of the of Zaporozhia city and is informally known as Verhnya Khortytsya.

The building was built in 1895 and at the time of the inspection, it fully functions as a school (Fig. 1). Since its construction, a minor architectural replanning, replacement of roofing materials, replacement of the heating system have been implemented. Basement, in general, remained unchanged. In this case, structural elements of the building were not affected. However, over a long period of time, destruction occurred: the structures underwent some damage and deformation, the finishing layers were dilapidated.

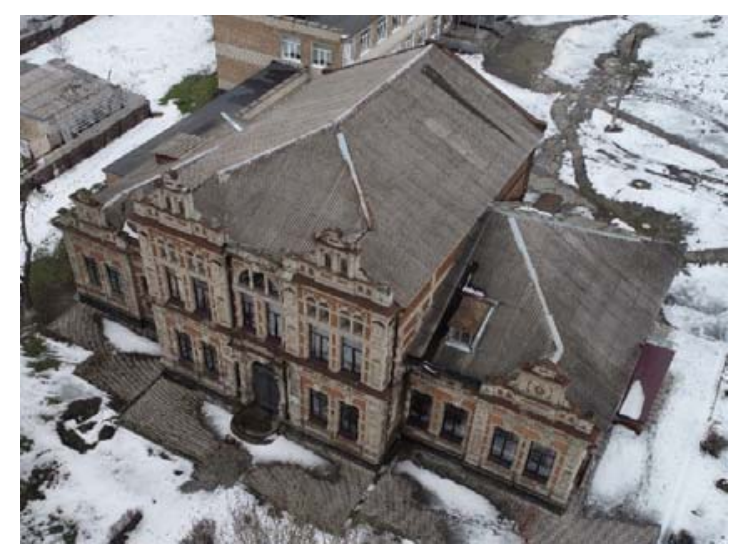

Fig. 1. Aerial overview of the building

A complex of inspection works was carried out, including a detailed visual inspection [7], determination of the strength of the material of some load-bearing structures, geodetic 
measurements, and model building using photogrammetric methods.

\section{3D Photogrammetry process}

Photogrammetry methods extract information from 2D photographs to reconstruct objects in $3 \mathrm{D}$. This technique, also known as image-based 3D modeling, uses structure-from-motion and stereo reconstruction algorithms to identify and match shared points from overlapping photographs to create point clouds and meshes representing the surface of an object.

Depending on the position (point of view) of a camera, photogrammetry can be classified as a terrestrial or areal.

Each part of the building should be photographed from at least three distinct - but not radically different - viewpoints. The overlap between consecutive photographs should typically exceed two thirds. For aerial photography, a longitudinal overlap of $80 \%$ and lateral overlap of $50 \%$ or more are recommended. Preparing a flight plan by preprogramming flight trajectory helps to achieve capturing pictures with sufficient and systematic overlap [8].

There are two major phases while acquiring a 3D model out of 2D pictures:

- Aerotriangulation that represents the mathematical process of establishing precise and accurate relationships between the individual image coordinate systems and a defined datum and projection (Fig. 2) [9]. One of the most fundamental processes in photogrammetry is to identify and measure tie points in several photographs, which is a part of the aerotriangulation process. The camera positions coordinates are determined during this process as well.

- Reconstruction of a 3D model. Through this phase, a 3D model (polygonal mesh or point cloud) is constructed using data acquired during aerotriangulation (tie points coordinates, camera positions).

The end-product of 3D photogrammetry is a precise $3 \mathrm{D}$ virtual model of a particular subject. An output model could be represented in different variations such as textured polygon mesh or point cloud depending on the purposes for the further use.
For school capturing the combination of aerial and terrestrial photogrammetry was chosen. Because of a high density of buildings, trees, power lines in surrounding area application of aerial capturing only would not have provided sufficient amount of pictures and overlap required for accurate result model.

The aerial images were taken with the UAV DJI Phantom, a compact sized quadcopter equipped with a built-in digital camera and active stabilizer (3-axis gimbal).

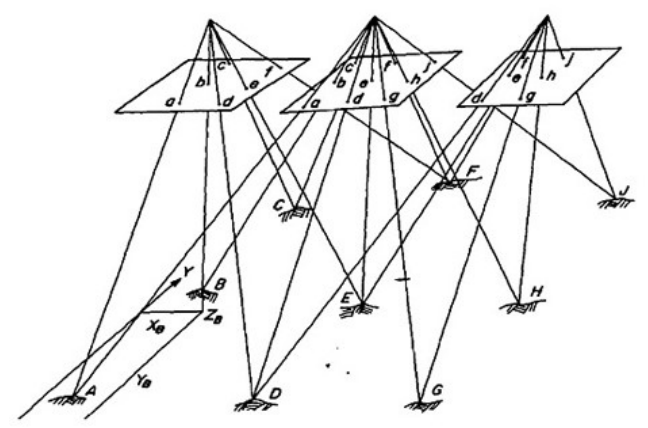

Fig. 2. Simplified scheme of aerotriangulation

Camera has a resolution of 20 megapixels; pictures taken with it contain metadata of GPS coordinates and altitude value from the built-in barometer.

Quadcopter was piloted in the polar coordinate system with the origin in the center of the building (Fig. 3). This made it possible to achieve consistency in picture capturing and sufficient overlap. In total, during the entire flight session, 141 photographic shots were taken.

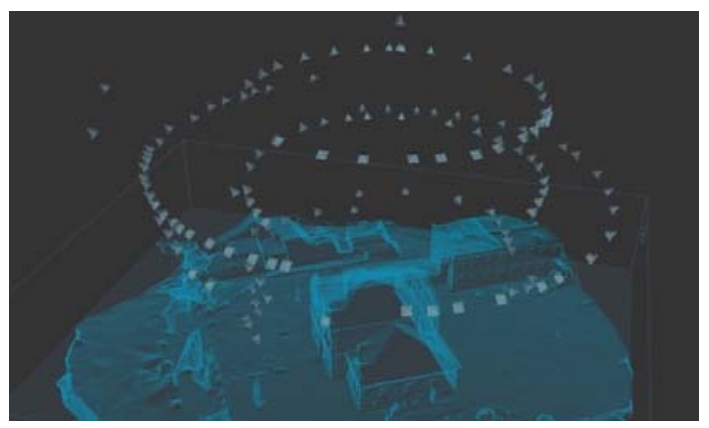

Fig. 3. UAV camera positions

To provide capturing of the lower part of the building as well as to capture architectural elements of the building with geometrically complex form, that is difficult to view from above, terrestrial pictures were taken. Eightyfive pictures were taken with action camera Xiaomi YI 4K. 


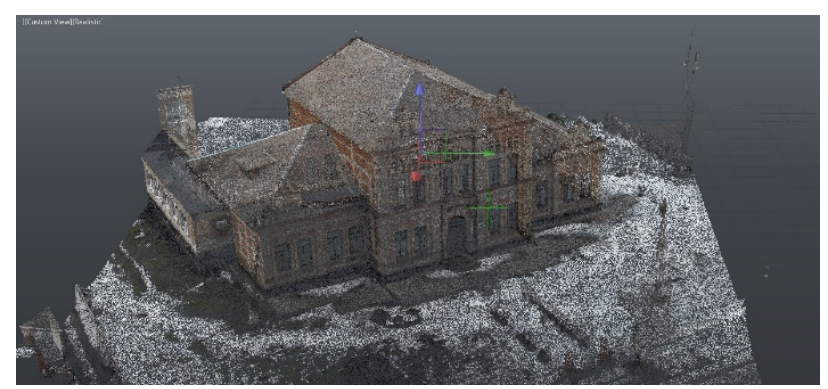

Fig. 4. 3D Point cloud result model. Prospective view

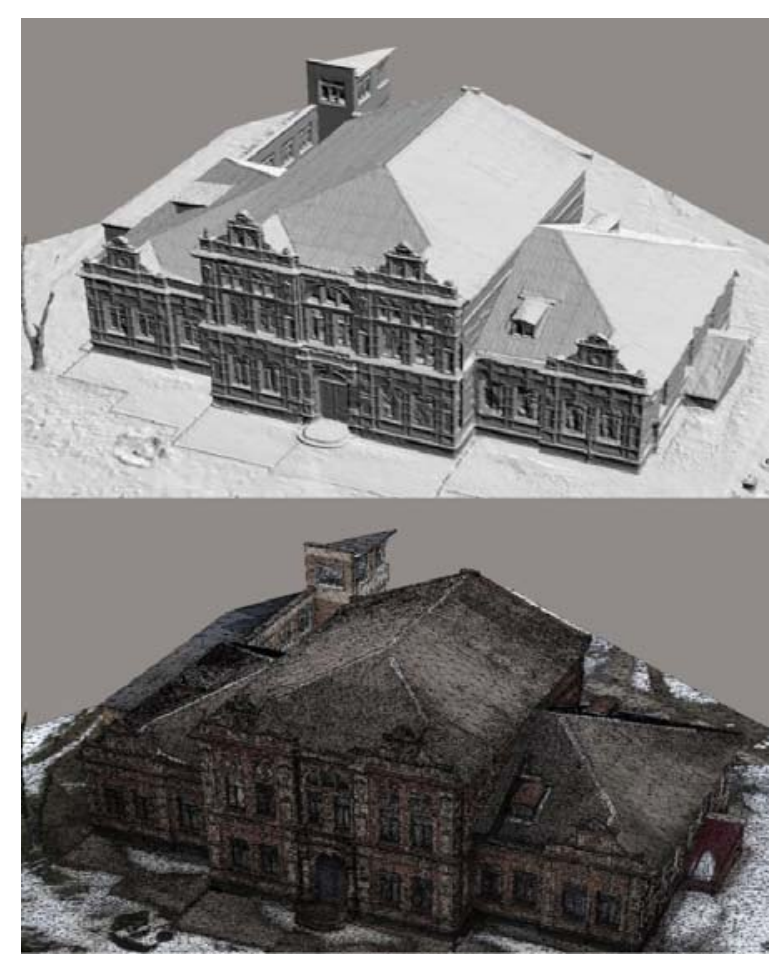

Fig. 5. - Textured and untextured result models

3D model was created with Autodesk Recap Photo software (ex- Autodesk Remake) in two variations - dense point cloud and high accurate polygonal textured mesh (Fig. 4, 5).

The workflow of ReCap photo is completely automated for image orientation, aerotriangulation and for generating and reconstructing the model. All operations that require computing power of computer are performed at cloud service. During this process, the human factor is minimized, i.e. limited on image and control points entering. The entire process of photogrammetry and modeling is automated, and no other human interference is necessary.

\section{Results of the inspection}

Based on the results of the inspection and capturing, defects were determined for individual structural and architectural elements, a cracking pattern, and technical measures for eliminating defects were elaborated.

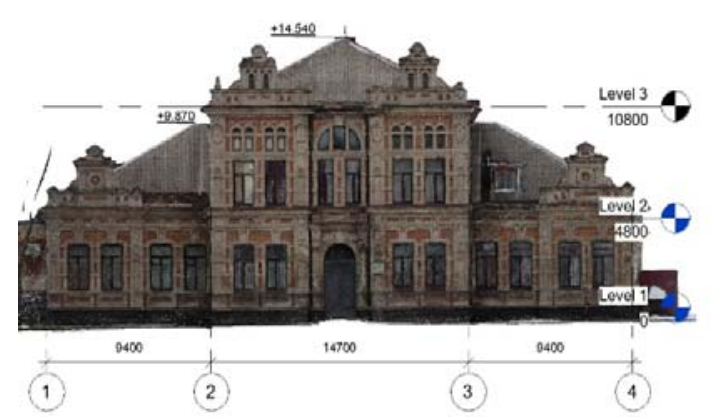

Fig. 6. Front elevation view

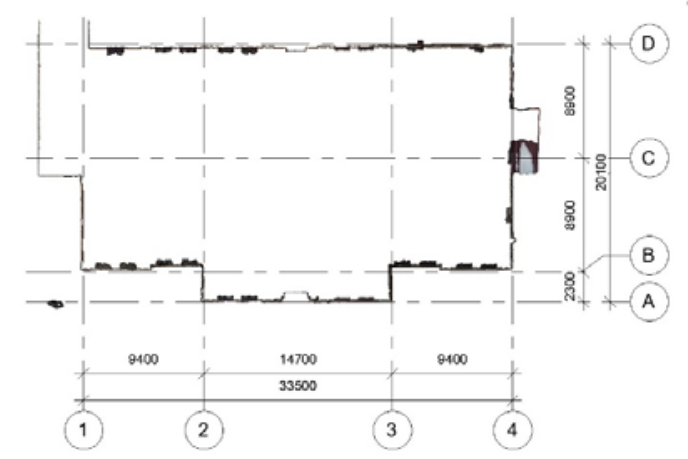

Fig. 7. Plan view

Damaged areas of the roof coating have been precisely identified through studying 3D textured mesh model in terms of both quantity and quality, which is challenging to do with traditional methods of inspection.

The obtained model was successfully used for documentation of structural and architectural elements and the building itself. Main drawings of existing building were semiautomatically created in Autodesk Revit BIM software with the help of background 3D point cloud model (Fig. 6-7). Creation such documentation with traditional methods of inspection would take a great deal of time and human resources with lack of detail and accuracy.

\section{Conclusion}

Today, the preservation of monuments, the renewal and the restoration of historical buildings and structures is an integral part of the national culture. However, such work requires serious efforts of many specialists to perform proper diagnosis of the causes of destruction and the application of effective repair and finishing materials, as well as the valuation of financial investments. 
The application of photogrammetry allowed providing full documentation of the building in a short time with minimum amount of human resources as well as assessing the technical condition of its elements including in hard-toreach places.

The combined photogrammetry method including aerial and terrestrial capturing has shown its effectiveness, especially for an inspection of landmarked buildings due to their complexity in form and density of obstacles around.

Thus, it is clearly shown that the presented inspection technique significantly reduces labor intensity and raises the efficiency of building and structures inspection.

\section{REFERENCES}

1. Bilis T., Kouimtzoglou T., Magnisali M. and Tokmakidis P. The use of 3 d scanning and photogrammetry techniques in the case study of the roman theatre of nikopolis. Surveying, virtual reconstruction and restoration study. The International Archives of the Photogrammetry, Remote Sensing and Spatial Information Sciences: 3D Virtual Reconstruction and Visualization of Complex Architectures, (1-3 March 2017, Nafplio, Greece). Nafplio, 2017, vol. XLII-2/W3, pp. 97-103.

2. Pejić P., Krasić S., Krstić H., Dragović M. and Akbiyik Y. 3D Virtual Modelling of Existing Objects by Terrestrial Photogrammetric Methods - Case Study of Barutana. Tehnički vjesnik. 2017, vol. 24, suppl. 1, pp. $233-239$.

3. Barrile V., Bilotta G. and Nunnari A. 3D modeling with photogrammetry by uavs and model quality verification. ISPRS Annals of the Photogrammetry, Remote Sensing and Spatial Information Sciences. 2017, vol. IV-4/W4, pp. 129-134.

4. Murtiyoso A., Remondino F., Rupnik E., Nex F. and Grussenmeyer P. Oblique Aerial Photography Tool for Building Inspection and Damage Assessment. The International Archives of the Photogrammetry, Remote Sensing and Spatial Information Sciences. 2014, vol. XL-1, pp. 309-313.

5. Ellenberg A., Kontsos A., Bartoli I. and Pradhan A. Masonry crack detection application of an unmanned aerial vehicle. Computing in civil and building engineering. 2014, vol. 3, pp. 1788-1795.

6. Arkhitektura menonitiv. Vid mynuloho do maibutnoho [Mennonite architecture. From the past to the future.]. Melitopol: Vydavnychyi budynok Melitopolskoi miskoi drukarni, 2010, 660 p. (in Ukrainian).

7. Texnicheskij osmotr konstruktivnyx elementax zdaniya №18 ul. Ystomina, g. Zaporozh'e: otchet: 6360 [Technical inspection of structural elements of building no. 18 Istomin st., Zaporizhia city: report: 6360]. OOO «Nastroj» [LLC «Nastroj»]. Zaporozh'e, 2012. (in Russian).

8. ReCap Learning Support. Help Home. Autodesk Recap Online Help. Available at: https://help.autodesk.com/view/RECAP/2018/ENU/. (Accessed on July 12, 2018)

9. Schenk T. Introduction to Photogrammetry. Columbus: The Ohio State University, 2005, $95 \mathrm{p}$.

\section{СПИСОК ВИКОРИСТАНИХ ДЖЕРЕЛ}

1. The use of $3 \mathrm{~d}$ scanning and photogrammetry techniques in the case study of the roman theatre of nikopolis. Surveying, virtual reconstruction and restoration study / T. Bilis, T. Kouimtzoglou, M. Magnisali, P. Tokmakidis // The International Archives of the Photogrammetry, Remote Sensing and Spatial Information Sciences : 3D Virtual Reconstruction and Visualization of Complex Architectures, (1-3 March 2017, Nafplio, Greece). - Nafplio, 2017. Vol. XLII-2/W3. - P. 97-103.

2. 3D Virtual Modelling of Existing Objects by Terrestrial Photogrammetric Methods - Case Study of Barutana / P. Pejić, S. Krasić, H. Krstić, M. Dragović, Y. Akbiyik // Tehnički vjesnik. - 2017. - Vol. 24, suppl. 1. - P. $233-239$.

3. Barrile V. 3D modeling with photogrammetry by uavs and model quality verification / V. Barrile, G. Bilotta, A. Nunnari // ISPRS Annals of the Photogrammetry, Remote Sensing and Spatial Information Sciences. - 2017. Vol. IV-4/W4. - P. 129-134.

4. Oblique Aerial Photography Tool for Building Inspection and Damage Assessment / A. Murtiyoso, F. Remondino, E. Rupnik, F. Nex, P. Grussenmeyer // The International Archives of the Photogrammetry, Remote Sensing and Spatial Information Sciences. - 2014. - Vol. XL-1. - P. 309-313.

5. Masonry crack detection application of an unmanned aerial vehicle / A. Ellenberg, A. Kontsos, I. Bartoli, A. Pradhan // Computing in civil and building engineering. - 2014. - Vol. 3. - P. 1788-1795.

6. Архітектура менонітів. Від минулого до майбутнього. Пер. 3 англ. - Мелітополь : Видавничий будинок Мелітопольскої міської друкарні, 2010. - 660 с.

7. Технический осмотр конструктивных элементах здания №18 ул. Истомина, г. Запорожье : отчет : 6360 / ООО «Настрой». - Запорожье, 2012.

8. ReCap Learning Support // Help Home. Autodesk Recap Online Help. - Режим доступу: https://help.autodesk.com/view/RECAP/2018/ENU/. - Перевірено: 12.07.2018.

9. Schenk T. Introduction to Photogrammetry / T. Schenk. - Columbus : The Ohio State University, 2005. - 95 p.

Рецензент: Шатов С. В., д-р техн. наук, проф.

Надійшла до редколегії: 07.12.2017 p. 